Illinois State University

ISU ReD: Research and eData

Theses and Dissertations

4-8-2014

\title{
The Effects Of Invasive Macrophytes Phragmites Australis And Typha Angustifolia On Nitrate Removal In High Nitrate Wetland Sediments
}

Lauren Mackenzie Beal

Illinois State University, lauren2beal@gmail.com

Follow this and additional works at: https://ir.library.illinoisstate.edu/etd

Part of the Biology Commons, and the Ecology and Evolutionary Biology Commons

\section{Recommended Citation}

Beal, Lauren Mackenzie, "The Effects Of Invasive Macrophytes Phragmites Australis And Typha Angustifolia On Nitrate Removal In High Nitrate Wetland Sediments" (2014). Theses and Dissertations. 98.

https://ir.library.illinoisstate.edu/etd/98

This Thesis is brought to you for free and open access by ISU ReD: Research and eData. It has been accepted for inclusion in Theses and Dissertations by an authorized administrator of ISU ReD: Research and eData. For more information, please contact ISUReD@ilstu.edu. 
THE EFFECTS OF INVASIVE MACROPHYTES PHRAGMITES AUSTRALIS AND TYPHA ANGUSTIFOLIA ON NITRATE REMOVAL IN HIGH NITRATE WETLAND SEDIMENTS

\author{
Lauren M. Beal
}

36 Pages

May 2014

Constructed wetlands are quickly becoming inundated with non-native species such as Phragmites australis and Typha angustifolia which are capable of changing whole ecosystem function and community composition. I assessed how plants affect nitrate $\left(\mathrm{NO}_{3}-\mathrm{N}\right)$ removal rates, dissolved organic carbon (DOC) and dissolved oxygen (DO) concentrations relative to barren sediments. Using a $\mathrm{NO}_{3}-\mathrm{N} / \mathrm{Br}$ tracer test, I examined $\mathrm{NO}_{3}-\mathrm{N}$ removal rates, $\mathrm{DO}$ and DOC concentrations in interstitial porewater. After the tracer test, I measured above- and below-ground plant biomass and sediment characteristics. I used a multivariate analysis of variance (MANOVA) and a post hoc Ryan-Einot-Gabriel-Welsch Multiple Range Test (REGWQ) to analyze the data. $\mathrm{NO}_{3}-\mathrm{N}$ removal did not differ across the planted and barren sediment microcosms $(\mathrm{P}>0.05)$. DOC concentrations were significantly higher in planted microcosm interstitial porewater than barren sediment microcosm interstitial porewater $(\mathrm{P}<0.05)$ but did not differ by species. DO was not detected during the tracer test, and thus was not used in the data analysis. Phragmites australis microcosms had significantly higher sediment bulk density 
compared and to T. angustifolia and barren sediment microcosms $(\mathrm{P}<0.05) . T$. angustifolia had higher sediment organic matter concentrations than the other two microcosms $(\mathrm{P}<0.05)$. Despite no detectible DO in the microcosms and significantly higher DOC concentrations in planted microcosms, $\mathrm{NO}_{3}-\mathrm{N}$ removal was not different across treatments. If DO is being used preferentially by sediment microbes, then $P$. australis and T. angustifolia could be inhibiting $\mathrm{NO}_{3}-\mathrm{N}$ removal through oxygen production in the roots. The low concentrations of DOC $(2.8-3.9 \mathrm{mg} / \mathrm{L})$ present in the rhizosphere may be composed of refractory organic carbon, which would not be accessible to sediment microbes as a carbon source for denitrification. The rhizosphere does not appear to facilitate $\mathrm{NO}_{3}-\mathrm{N}$ removal, and in fact may inhibit removal. Detritus and organic matter build up through deposition of aboveground biomass by macrophytes and algae may drive $\mathrm{NO}_{3}-\mathrm{N}$ removal. 
THE EFFECTS OF INVASIVE MACROPHYTES PHRAGMITES AUSTRALIS AND TYPHA ANGUSTIFOLIA ON NITRATE REMOVAL IN HIGH NITRATE WETLAND SEDIMENTS

\author{
LAUREN M. BEAL
}

A Thesis Submitted in Partial Fulfillment of the Requirements for the Degree of

MASTER OF SCIENCE

School of Biological Sciences

ILLINOIS STATE UNIVERSITY 
All rights reserved

INFORMATION TO ALL USERS

The quality of this reproduction is dependent upon the quality of the copy submitted.

In the unlikely event that the author did not send a complete manuscript and there are missing pages, these will be noted. Also, if material had to be removed, a note will indicate the deletion.

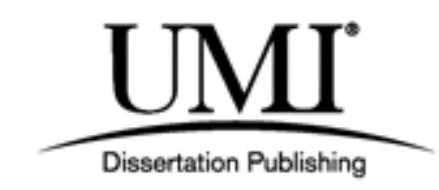

UMI 1562456

Published by ProQuest LLC (2014). Copyright in the Dissertation held by the Author.

Microform Edition () ProQuest LLC.

All rights reserved. This work is protected against unauthorized copying under Title 17, United States Code

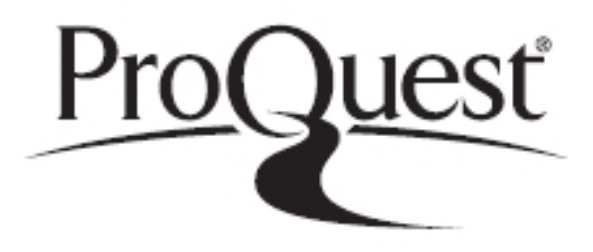

ProQuest LLC.

789 East Eisenhower Parkway

P.O. Box 1346

Ann Arbor, MI 48106 - 1346 
C 2014 Lauren M. Beal 
THE EFFECTS OF INVASIVE MACROPHYTES PHRAGMITES AUSTRALIS AND TYPHA ANGUSTIFOLIA ON NITRATE REMOVAL IN HIGH NITRATE WETLAND SEDIMENTS

\author{
LAUREN M. BEAL
}

COMMITTEE MEMBERS:

William L. Perry, Chair

Catherine M. O’Reilly

Victoria A. Borowicz 


\section{ACKNOWLEDGMENTS}

I would like to thank my committee, Dr. William Perry, Dr. Catherine O’Reilly, and Dr. Victoria Borowicz for their invaluable assistance in every aspect of my research. Thank you to Brian Grebliunas, Krista Kirkham, and Laura Zimmerman for their help, humor, and friendship throughout my research. Also, thank you to Rafael Brandão for his assistance.

Thank you to my family for their love and support. I am grateful to them for instilling a curiosity in the natural world as well as teaching me the value of hard work and determination. Thank you to Alex Weihs for being so supportive while I have pursued my passion, you have been a tremendous help in this process.

L.M.B. 


\section{CONTENTS}

\section{Page}

ACKNOWLEDGMENTS $\quad$ i

CONTENTS

TABLES

FIGURES

CHAPTER

I. INTRODUCTION 1

Question and Hypotheses $\quad 4$

$\begin{array}{lll}\text { II. } & \text { METHODS }\end{array}$

Microcosm Setup 6

Testing $\mathrm{NO}_{3}-\mathrm{N}$ Removal Using A Microcosm Push-Pull Test 8

Sample Analysis 9

Data Analysis $\quad 12$

$\begin{array}{ll}\text { III. } & 14\end{array}$

$\begin{array}{ll}\text { IV. DISCUSSION } & 27\end{array}$

$\mathrm{NO}_{3}-\mathrm{N}$ Removal 27

Dissolved Organic Carbon 28

Dissolved Oxygen $\quad 29$

Sediment Dry Bulk Density 30

Sediment Organic Matter $\quad 31$

$\begin{array}{ll}\text { Summary } & 32\end{array}$

$\begin{array}{ll}\text { REFERENCES } & 34\end{array}$ 


\section{TABLES}

Table $\quad$ Page

1. MANOVA Results For All Response Variables And Comparisons.

2. MANCOVA Results For The Dry Root Biomass Covariate And Treatment Interaction

3. MANCOVA Results Showing The Effect Of The Covariate Dry Root Biomass By Treatment

4. MANCOVA Results Showing The Least Square Means Of The Planted Treatments 


\section{FIGURES}

Figures

1. Mean $\mathrm{NO}_{3}-\mathrm{N}$ Removal Results (mg/L) By Each Treatment. Error Bars Represent +/- 1 Standard Error. Means With The Same Letter Are Not Significantly Different Using The REGWQ Method For Pairwise Comparisons.

2. Mean Dissolved Organic Carbon (mg/L) For Each Treatment. Error Bars Represent +/- 1 Standard Error. Means With The Same Letter Are Not Significantly Different Using The REGWQ Method For Pairwise Comparisons.

3. Mean Sediment Dry Bulk Density $\left(\mathrm{g} / \mathrm{cm}^{3}\right)$ For Each Treatment. Error Bars Represent +/- 1 Standard Error. Means With The Same Letter Are Not Significantly Different Using The REGWQ Method For Pairwise Comparisons.

4. Mean Percent Sediment Organic Matter By Volume For Each Treatment. Error bars represent +/- 1 Standard Error. Means With The Same Letter Are Not Significantly Different Using The REGWQ Method For Pairwise Comparisons.

5. Mean Dry Root Biomass Were Significantly Different Between $P$. australis and T. angustifolia. Error Bars Represent +/- 1 Standard Error.

6. Mean Dry Shoot Biomass (g) Was Not Significantly Different Between $P$. australis And T. angustifolia Treatments. Error Bars Represent +/- 1 Standard Error. 


\section{CHAPTER I}

\section{INTRODUCTION}

Over $90 \%$ of the 8 million acres of wetlands that once covered the state of Illinois have been destroyed (Suloway and Hubbell 1994). As of 1994, wetlands covered only $3.5 \%$ (1.25 million acres) of land in Illinois. Historically, wetlands served as a prime nesting and stopover habitat for migratory waterfowl in the Midwest. Extensive wetlands likely served an important ecological function in groundwater recharge, slowing water flow, and as a site for nutrients to be removed (Brinson et al. 1984; Zedler 2003). The loss of wetlands also meant a loss in ecological functions such as habitat for plants and wildlife, storage of storm waters, and potential nutrient retention locations (Mistch and Gosselink 2000). The loss of wetlands occurred with a commensurate increase of agricultural use and application of fertilizers that has led to eutrophication of local and downstream systems impairing water and habitat quality. Restoration of wetland habitats is now considered a priority in protecting water supplies and reducing nutrient loading (Suloway and Hubbell 1994, Mitsch et al. 2005).

Constructed wetlands are being created at a rapid rate to provide habitat for wildlife as well as to reduce nitrogen and phosphorus loads from surface and tile run-off (Suloway and Hubbell 1994, Mitsch et al. 2005). Construction of artificial wetlands causes a large amount of disturbance in the landscape. Often sediment is left bare, with the intent of native plants to colonize it through the seed bank within the sediment in and 
around newly constructed wetlands. However, many invasive species thrive under disturbed conditions, with seeds dispersing via the wind and germinating easily in the moist, nutrient rich sediment. Combined with the opportunity to grow unimpeded by competition, increased nitrogen inputs seems to encourage invasive macrophytes, such as Phragmites australis, the common reed, and Typha angustifolia, the narrowleaf cattail (Rickey and Anderson 2004).

Invasive plant species, like $P$. australis and $T$. angustifolia, are capable of changing whole ecosystem function and community composition (Vitousek et al. 1996). These two invasive species are capable of displacing native species with the help of allelopathic root exudates, which can hinder the growth of nearby plants (Callaway and Ridenour 2004). Additionally, they often grow in dense, monospecific stands, with extensive root systems, which harbor specific microbial communities (Angeloni et al. 2006). Specific microbial communities, which can include bacteria and mycorrhizal fungi, occupy the root-sediment interface that is influential in the chemical, biological, and physical processes occurring in the sediment (Pinton et al. 2007). Due to the complexity of a plant's root system, the exact definable area of the rhizosphere is difficult to quantify as it depends on the properties of a plants root morphology and release of root exudates. $P$. australis and T. angustifolia both have similar root system morphology that consists of large roots, or rhizomes, and smaller root hairs. The toxic allelopathic root exudates released into the rhizosphere may be a carbon source for the microbial communities in the rhizosphere. While the plants compete for space above- and belowground, they are also competing for limited nutrients with other plants and 
potentially with microbes. However, how this potential competitive interaction plays out in terms of nutrient removal is still relatively unknown.

The relationship between plants and microbes is contentious, and what defines the community within the rhizosphere is still relatively unknown though the sediment type, region under study, host plant, and phenolics released by the host plant seem to play a large role (Callaway et al. 2004, 2008, Yannarell et al. 2011). Bacteria specializing in denitrification are responsible for removing the majority of inorganic nitrogen from the water and sediments by reducing nitrate to nitrogen gas. Nitrogen gas is released into the atmosphere and leaves the system permanently, unless microbial nitrogen fixation occurs. The microbial community structure differs among plant species, and this can affect denitrification rates from within the rhizosphere and sediments if the environment is not favorable to denitrifying bacteria (Park et al. 2009). The plants under study also pump oxygen down to their roots, and this could reduce nitrogen denitrification by microbes. Phragmites australis releases gallic acids such as 3,4,5-trihydoxybenzoic acid and other gallotannins while $T$. angustifolia releases a variety of phenolic acids such as ohydroxycinnamic acid, syringic acid, and isoferulic acid (Rudrappa et al. 2009, and Zhang et al. 2011) that could favor or impede the development of denitrifying bacteria in sediments. Phenolics can inhibit plant growth and may also inhibit the growth of microbes that are in competition with the plants for nutrients.

Whole-wetland studies have shown nitrate removal increases with the presence of plants, and sometimes with the presence of an invasive plant (Lin et al. 2002). The mechanism behind the increase in whole-wetland nitrate removal could be the carbon being released by senescent plant matter, or from phenolic acids released from roots as 
exudates. Although P. australis (common reed) and T. angustifolia (narrowleaf cattail) are similar, they may differ in their: specific phenolic acids released into the sediments; accumulation of biomass; timing of senescence which may all affect rhizopshere microbial communities and nitrate removal rates. The presence of $P$. australis and $T$. angustifolia may enhance nitrogen removal rates when the sediments are under anoxic conditions. Information regarding nitrate removal by individual plants and the microbes they interact with is limited, and may provide a clearer picture into the process of removing nitrate from the system. The objective of this study is to determine in situ nitrogen removal rates as affected by two common invasive macrophytes, $P$. australis and $T$. angustifolia. I hypothesized the macrophytes increase concentrations of dissolved organic carbon and $\mathrm{NO}_{3}-\mathrm{N}$ removal rates relative to barren sediments, however removal may be limited by dissolved oxygen production.

\section{Question and Hypotheses}

How do macrophytes, Typha angustifolia and Phragmites australis, affect dissolved oxygen (DO) and dissolved organic carbon concentrations (DOC), and in turn modify nitrate $\left(\mathrm{NO}_{3}-\mathrm{N}\right)$ removal rates relative to barren sediments?

There are three hypotheses considered in this study:

1) The macrophytes increase concentrations of dissolved organic carbon, decrease dissolved oxygen concentrations, and thus increase nitrate removal rates in interstitial porewater relative to barren sediments. 
2) The macrophytes increase concentrations of dissolved organic carbon, increase dissolved oxygen concentrations, and thus decrease nitrate removal rates in interstitial porewater relative to barren sediments.

3) The null hypothesis is there are not differences in nitrate removal rates. 


\section{CHAPTER II}

\section{METHODS}

\section{Microcosm Setup}

To test the species effect of $P$. australis and T. angustifolia on $\mathrm{NO}_{3}-\mathrm{N}$ removal, DO and DOC release in wetland sediments, treatments consisted of $P$. australis alone $(\mathrm{N}=10)$, . angustifolia $(\mathrm{N}=10)$ alone, and a control of barren sediments $(\mathrm{N}=10)$. Wetland sediment was collected from a well-characterized, tile-drained, constructed wetland west of Lexington, IL (40³8' 24.27", -88 49' 32.4402"). Sediment samples were taken from one wetland in a complex of three depression-type wetlands that are 10 years old. In these wetlands, aquatic plants such as floating-leaf pondweed (Potamogeton natans) and broadleaf arrowhead (Sagittaria latifolia) were found in low densities in addition to green algae. The emergent zone of the wetland consisted of reed canary grass (Phalaris arundinacea). Drainage tiles are the only inflow from the surrounding agricultural fields planted in corn for the past 4 years. The sediment was collected from under $10 \mathrm{~cm}$ of water and had no plants growing in it. The upper $10 \mathrm{~cm}$ of sediment was collected in buckets and transported back to campus. Upon return to campus, the sediments were homogenized and placed in 5 gallon buckets that served as microcosms with a depth of $15 \mathrm{~cm}$. Large, extraneous litter and detrital matter was removed from the microcosms prior to planting the macrophytes and installing the piezometers. The rhizomes of the 
plants were rinsed and planted in microcosms within 4 hours of being collected. Bare sediment microcosms were homogenized to simulate planting conditions.

To replicate field densities of macrophytes in the microcosms, I assessed field densities using a point intercept survey during the growing season. Three random points consisting of $1 \mathrm{~m}^{2}$ quadrats were used to establish the mean field density for $P$. australis and T. angustifolia. After the survey, macrophytes were collected with intact rhizomes to ensure new growth would occur during the acclimation period. P. australis was collected on the north side of Lake Bloomington, near Hudson, IL, from a perched wetland $\left(40^{\circ} 39^{\prime}\right.$ 45.4098-88 56' 12.4044"). T. angustifolia was collected from a tile-drained grass waterway adjacent to a series of 3 connected constructed wetlands near Colfax, IL ( $40^{\circ}$ $\left.29^{\prime} 0.6534^{\prime \prime},-88^{\circ} 37^{\prime} 10.686^{\prime \prime}\right)$. Mean field densities for $P$. australis were $102 \mathrm{plants} / \mathrm{m}^{2}$ and 34 plants $/ \mathrm{m}^{2}$ for T. angustifolia. Microcosms were planted with approximately $17 P$. australis and 5 T. angustifolia plants per microcosm which approximated field densities.

Microcosms were maintained in a greenhouse with high-pressure sodium lighting for an acclimation period of one month. Photoperiods were $14 \mathrm{hr}$ light and $10 \mathrm{hr}$ dark. Surface water volumes were maintained at $2 \mathrm{~L}$ with $20 \mathrm{mg} / \mathrm{L}$ nitrate $\left(\mathrm{NO}_{3}-\mathrm{N}\right)$, using tap water as a proxy for tile water. Tile and tap water have low concentrations of dissolved organic carbon (DOC), which is ideal to use when testing the amount of DOC the macrophytes are releasing from the roots. The air temperatures ranged from $25-30^{\circ} \mathrm{C}$. 


\section{Testing $\mathrm{NO}_{3}$-N Removal Using A Microcosm Push-Pull Test}

To test removal rates of $\mathrm{NO}_{3}-\mathrm{N} 3$ piezometers were installed in each microcosm within the rhizosphere of the plants in the treatment microcosms and randomly distributed in bare sediment microcosms. The piezometers consist of a screen mesh (2 $\mathrm{mm}$ ) at the tip of a polysterene $1 \mathrm{~mL}$ pipette. PVC tubing was attached to the top of the pipette, and was connected to a luer-lock $60 \mathrm{~mL}$ syringe. The test solution of $180 \mathrm{~mL}$ of $20 \mathrm{mg} / \mathrm{L}$ of a 1:1 ratio of $\mathrm{NO}_{3}-\mathrm{N}: \mathrm{Br}$ was injected into the sediment through each piezometer. Preliminary tests suggested 3 hours a sufficient amount of time to observe significant removal, but still maintaining detectible concentrations of $\mathrm{NO}_{3}-\mathrm{N}$ and $\mathrm{Br}$. After incubating for 3 hours, the porewater and test solution were extracted through the same piezometers. Before each injection, sediment and water temperatures were recorded along with surface water DO. Prior to injection, porewater was drawn into the piezometer and tygon tubing to prevent oxygen from being introduced into the sediments. The solution was then pushed slowly into the sediments so that the sediments were not disturbed and porewater did not mix with surface water. Upon extraction, the porewater was pulled up from the sediments and when the piezometer was filled with water, the air in the syringe was evacuated and the sample was collected. Multiple syringes were used to collect porewater samples and the tubing was pinched closed to prevent losing water pressure in the piezometer as well as prevent introducing oxygen into the sample when a new syringe was used to collect a sample. One syringe was used to collect water for DO analysis, while the other was used to collect samples for $\mathrm{NO}_{3}-\mathrm{N} / \mathrm{Br}$ and $\mathrm{DOC}$ analysis. Samples that would be used for the Winkler Titration were immediately fixed in the syringe they were collected in. Samples used for $\mathrm{NO}_{3}-\mathrm{N} / \mathrm{Br}$ and DOC analysis were 
filtered through a pre-combusted $0.45 \mu \mathrm{m}$ Millipore glass fiber prefilter (Type AP40) and refrigerated.

\section{Sample Analysis}

To estimate dissolved oxygen (DO) concentrations a Winkler Titration was used. Water collected in $60 \mathrm{~mL}$ syringes was fixed using $200 \mu \mathrm{L}$ of manganese sulfate solution (36.4 $\mathrm{g} \mathrm{MnSO}_{4} \cdot \mathrm{H}_{2} \mathrm{O} / 100 \mathrm{~mL}$ distilled water) and $200 \mu \mathrm{L}$ of stock alkaline potassium iodide (1 N KI in $\mathrm{NaOH})$. During fixation the solution was mixed and sealed in the syringe, maintained at $4^{\circ} \mathrm{C}$, and titrated within 8 hours of collection. Prior to titration of the sample, $200 \mu \mathrm{L}$ of concentrated sulfuric acid was pipetted into the syringe. The sulfuric acid dissolved the manganic oxide (the tan floc), which oxidized the iodide to iodine. The sample was filtered to remove sediment using a $0.45 \mu \mathrm{m}$ filter and vacuum pump. The filtered sample was added to an Erlenmeyer flask. The Erlenmeyer flask was placed below a $10 \mathrm{~mL}$ burette, and the solution was stirred using a magnetic stirrer and stir bar. Sodium thiosulfate $(0.025 \mathrm{~N})$ was used to titrate the iodine in the sample until it turned a light yellow, 3 drops of a starch indicator $(2 \mathrm{~g}$ soluble starch/100 $\mathrm{mL}$ distilled water) was used to estimate the end point. Adding the starch turned the solution blue, and more $0.025 \mathrm{~N}$ sodium thiosulfate was added until the solution was completely colorless.

The following equation was used to determine concentrations of DO from the Winkler Titration: $\quad \frac{m L \text { of titrant used } x \text { Normality of titrant } x 8000}{(\text { volume of sample }+0.6) \times\left(\frac{\text { volume of sample }-0.6}{\text { volume of sample }}\right)}=\mathrm{O}_{2} \mathrm{mg} / \mathrm{L}$

Bromide and nitrate concentrations from each piezometer were analyzed using a Dionex Ion Chromatograph. The amount of $\mathrm{NO}_{3}$ removed was the difference between $\mathrm{Br}$ and $\mathrm{NO}_{3}$ because the initial injection concentrations of $\mathrm{Br}$ and $\mathrm{NO}_{3}-\mathrm{N}$ were the same. 
To estimate porewater DOC concentrations, the UV absorption was estimated using absorbance on a UV-visible spectrophotometer (Tipping et al. 2009). The specific absorbance or extinction coefficient (E) of natural DOC can be determined as the ratio between a wavelength and the concentration of DOC, as found from high temperature catalytic oxidation (Thacker et al. 2008). However, Thacker et al. (2008) found that the ratio of $E_{340} / E_{254}$ consistently matched the increase in $E_{340}$, which indicates that DOC concentrations can be deduced from absorbance values alone. Not only is this cheaper, but the data can be acquired quickly using just two wavelengths on the UV-Visible Spectrophotometer to obtain the necessary ratio. The two wavelengths used by Tipping et al. (2009) to measure absorbance were $254 \mathrm{~nm}\left(\mathrm{UV}_{254}\right)$ and $340 \mathrm{~nm}\left(\mathrm{UV}_{340}\right)$ using a 1.0 cm quartz cuvette. Since the ratios of $\mathrm{E}_{340} / \mathrm{E}_{254}$ and $\mathrm{A}_{340} / \mathrm{A}_{254}$ are the same, $\mathrm{A}_{340} / \mathrm{A}_{254}$ can be represented as $\mathrm{E}_{340}$, and $\mathrm{E}_{340} / \mathrm{A}_{254}$ can be used to quantify DOC concentrations.

To estimate above and belowground plant biomass, plants from each microcosm were harvested, the sediment rinsed from the roots, and the roots and shoots were separated. To obtain the total dry mass, the roots and shoots were dried at $100^{\circ} \mathrm{C}$ for 24 hours, and reweighed. Ash-free dry mass (AFDM) was obtained by combusting 3 replicates of approximately 1 gram of root and shoot mass from each microcosm in a muffle furnace at $540^{\circ} \mathrm{C}$ for 24 hours, and the mass was recorded and AFDM was estimated as the difference between the dry weight at remaining ash.

During the plant harvest, sediment was also sampled for dry bulk density and organic matter concentrations. Samples were taken from around the roots, placed in plastic bags, and refrigerated. Triplicate samples of approximately $5 \mathrm{~g}$ of wet sediment were dried at $100^{\circ} \mathrm{C}$ for 24 hours and the dry mass was recorded. After the drying period, 
the sediment was combusted in a Thermolyne muffle furnace at $500^{\circ} \mathrm{C}$ for 16 hours, and the resulting ash weight was subtracted from the dry weight and this represented the sediment organic matter. A significant increase in inorganic material loss can occur when sediment samples are combusted above $500^{\circ} \mathrm{C}$ (Mook and Hoskin 1982). Organic matter was calculated as the difference between sediment dry mass and the AFDM. To put the organic matter values on the same scale for each treatment, organic matter values were analyzed as a percentage of the sediment dry mass.

To estimate sediment dry bulk density we used the wet, dry, and ash-free dry mass from 3 replicates of sediment samples taken from each microcosm (Avnimelech et al. 2001). The sediment bulk density was estimated as a means of determining how the macrophyte roots affected sediment characteristics that could potentially alter hydraulic conductivity. The following method was the preferred method because it required little handling aside from the initial sampling and could provide a lot of information, such as sediment bulk density, porosity, and hydraulic conductivity, in a few simple steps. However, to maintain a powerful test, the additional variables like porosity and hydraulic conductivity were not added to the statistical analysis. To calculate sediment dry bulk density the following equation was used:

Dry bulk density $\left(\mathrm{g} / \mathrm{cm}^{3}\right)=$ Weight, Dry sample $\left(W_{d}\right) /$ Total sample volume $\left(V_{t}\right)$

Dry bulk density $=\left(W_{d}\right) /\left(V_{t}\right)$ 
The total sample volume $\left(V_{t}\right)$ was calculated as the sum of the volume of particles $\left(V_{p}\right)$ and volume of water $\left(V_{w}\right)$, where water density is $1 \mathrm{~g} / \mathrm{cm}^{3}$ :

$$
\begin{aligned}
& V_{t}=V_{p}+V_{w} \\
& =\left(\frac{\text { weight of dry sample }}{\text { sediment particle density }}\right)+(\text { weight wet sample }- \text { weight of dry sample })
\end{aligned}
$$

The sediment particle density is generally $2.6-2.7 \mathrm{~g} / \mathrm{cm}^{3}$, but was corrected for organic particle density of $1.25 \mathrm{~g} / \mathrm{cm}^{3}$ since there was the potential for a significant fraction of the particles to be organic rather than inorganic (Blake and Hartge 1986, Boyd 1995). The equation from Boyd (1999) was used for weighed mean sediment particle density:

Weighed mean sediment particle density $\left(\mathrm{g} / \mathrm{cm}^{3}\right)$

$=(1.25(\%$ organic matter $)+2.65(100 \%-\%$ organic matter $))$

\section{Data Analysis}

A multivariate analysis of variance (MANOVA) was used to determine interaction among the variables tested $\left(\mathrm{NO}_{3}-\mathrm{N}\right.$ removal, DOC, DO, sediment dry bulk density, sediment organic matter, macrophyte root and shoot biomass). All of the variables except DO had three subsamples analyzed, and the mean of the subsamples was used in the analysis for a sample size of 10 per treatment (P.australis, T. angustifolia, barren sediment). Due to no detectable DO in any of the microcosms, DO was removed from the analysis to improve the tests power. The MANOVA analysis was conducted using SAS 9.2 statistical software. 
In order to estimate the effects plant biomass had on the response variables a multivariate analysis of covariance (MANCOVA) was conducted. Sediment microcosms were not analyzed because there were no roots to affect the response variables. The variable sediment organic matter was not normally distributed so it was inversely transformed to meet the assumptions of the MANCOVA. All of the other assumptions were met for the test. The MANCOVA was conducted using SAS 9.2 statistical software. 


\section{CHAPTER III}

\section{RESULTS}

The overall MANOVA model was significant for the effects of the treatments, as well as for the comparisons between $P$. australis and T. angustifolia, and $P$. australis and bare sediment microcosms (Table 1). Sediment dry bulk density accounted for the majority of the variation found in the model, with a standardized canonical coefficient of 1.007 (Table 1). For the treatment model, the least amount of variation was due to $\mathrm{NO}_{3}-\mathrm{N}$ removal which had a canonical coefficient of 0.118 , and DOC which had a canonical coefficient of 0.111 . MANOVA comparisons between $P$. australis vs. T. angustifolia and P. australis vs. barren sediments were significantly different with $\mathrm{P}$ values of 0.0006 and 0.0076, respectively. Barren sediment and T. angustifolia microcosms were not significantly different $(\mathrm{P}=0.0634)$. Because DO was not detectable, it was not included in the analysis.

To follow up the MANOVA and parse out where differences occurred among the treatments, a Ryan-Einot-Gabriel-Welsch Multiple Range Test (REGWQ) method was performed for each variable. The REGWQ method showed no significant differences in $\mathrm{NO}_{3}-\mathrm{N}$ removal means among the treatments $(\mathrm{P}>0.05)$ (Figure 1). DOC concentrations were significantly higher in planted microcosms than barren sediment microcosms $(\mathrm{P}<0.05)$, but did not differ across species $(\mathrm{P}>0.05)$ (Figure 2$)$. Sediment dry bulk density 
for $P$. australis was significantly higher than $T$. angustifolia and barren sediment microcosms $(\mathrm{P}<0.05)$, however there was no difference in bulk density between $T$. angustifolia and barren sediment microcosms $(\mathrm{P}>0.05)$ (Figure 3$)$. The sediment organic matter values were not normally distributed, and were inversely transformed for the MANOVA. T. angustifolia had a significantly higher percentage of organic matter in the sediments relative to $P$. australis and barren sediment microcosms $(\mathrm{P}<0.05)$ (Figure 4).

To determine if above- and belowground biomass was significantly different between $P$. australis and $T$. angustifolia a two-tailed t-test was conducted. The mean dry root biomasses were significantly different $(\mathrm{P}=0.4017)$ for $P$. australis was $90.27 \mathrm{~g}$ while the mean for T. angustifolia was $41.84 \mathrm{~g}$ (Figure 5). The aboveground dry biomass was not significantly different between the two plants, according to a two-tailed t-test $(\mathrm{P}=$ 0.4017) (Figure 6). Since the two root biomasses are significantly different, this could have affected the other variables tested in the MANOVA. To determine the extent of the effects from the dry root biomass, further analyses were necessary.

To understand differences caused by dry root biomass, which was a covariate in the planted microcosms, a multivariate analysis of covariance (MANCOVA) was conducted without the barren sediment treatment (Table 2). Slopes for the MANCOVA were equal across all of the variables tested and all of the variables were normally distributed (Table 2). The Shapiro-Wilk test for normality was used to assess normality, and the result was a p-value of 0.9691 , indicating a normal distribution. The root organic mass and treatment interactions were not significant $(\mathrm{P}>0.05)$ for any variable, so main effects were tested (Table 2). The covariate did have an effect on the concentrations of DOC in the rhizosphere, however the LS Means from the Tukey-Kramer test are not 
different between the two plant treatments $(\mathrm{P}=0.1037)$ (Table 4$)$. The mass of the roots in the rhizosphere affected the differences between $P$. australis and T. angustifolia treatments for sediment dry bulk density, and the LSMeans for the P. australis was greater than T. angustifolia $(\mathrm{P}=0.0038)($ Table 4$)$. Sediment organic matter percentages $(\mathrm{P}=0.0985)$ and $\mathrm{NO}_{3}-\mathrm{N}$ removal $(\mathrm{P}=0.6014)$ were not different. 
Table 1. MANOVA Results For All Response Variables And Comparisons.

\begin{tabular}{|c|c|c|c|c|c|c|c|}
\hline \multirow[t]{2}{*}{ Source } & \multirow{2}{*}{$\begin{array}{c}\text { Pillai's } \\
\text { Trace } \\
(F) \\
\end{array}$} & \multirow[t]{2}{*}{$d f$} & \multirow[t]{2}{*}{$\operatorname{Pr}>F$} & \multicolumn{4}{|c|}{ Standardized Canonical Coefficients } \\
\hline & & & & $\begin{array}{c}\mathrm{NO}_{3}-\mathrm{N} \\
\text { Removal }\end{array}$ & $\begin{array}{c}\% \text { Organic } \\
\text { Matter }\end{array}$ & $\begin{array}{c}\text { Dry Bulk } \\
\text { Density }\end{array}$ & DOC \\
\hline Treatment & 4.24 & 8,50 & 0.0006 & 0.118 & 0.675 & 1.006 & 0.111 \\
\hline P vs. S & 7.1 & 4,24 & 0.0006 & 0.150 & 0.718 & 0.969 & -0.002 \\
\hline P vs. T & 4.47 & 4,24 & 0.0076 & -0.040 & 0.373 & 1.000 & 0.592 \\
\hline $\mathrm{S}$ vs. T & 2.57 & 4,24 & 0.0634 & 0.304 & 0.701 & 0.291 & -0.785 \\
\hline
\end{tabular}




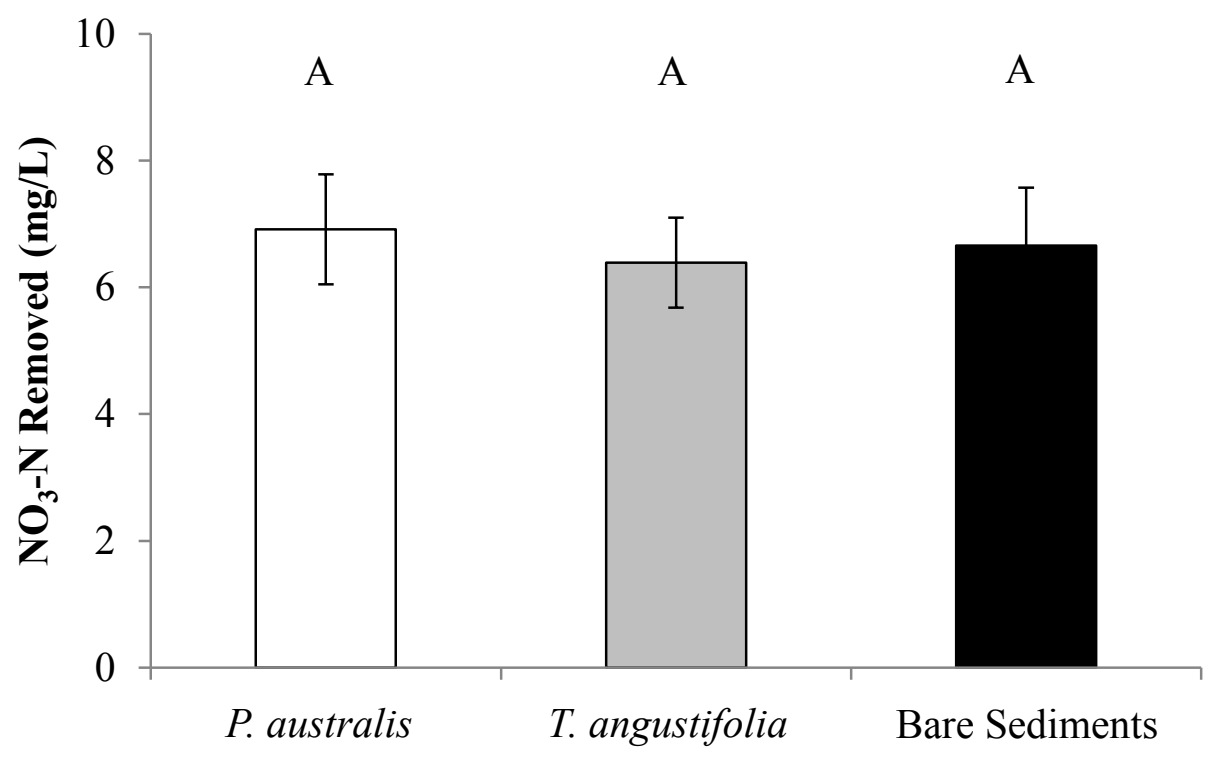

Figure 1. Mean $\mathrm{NO}_{3}-\mathrm{N}$ Removal Results (mg/L) By Each Treatment. Error Bars Represent +/- 1 Standard Error. Means With The Same Letter Are Not Significantly Different Using The REGWQ Method For Pairwise Comparisons. 


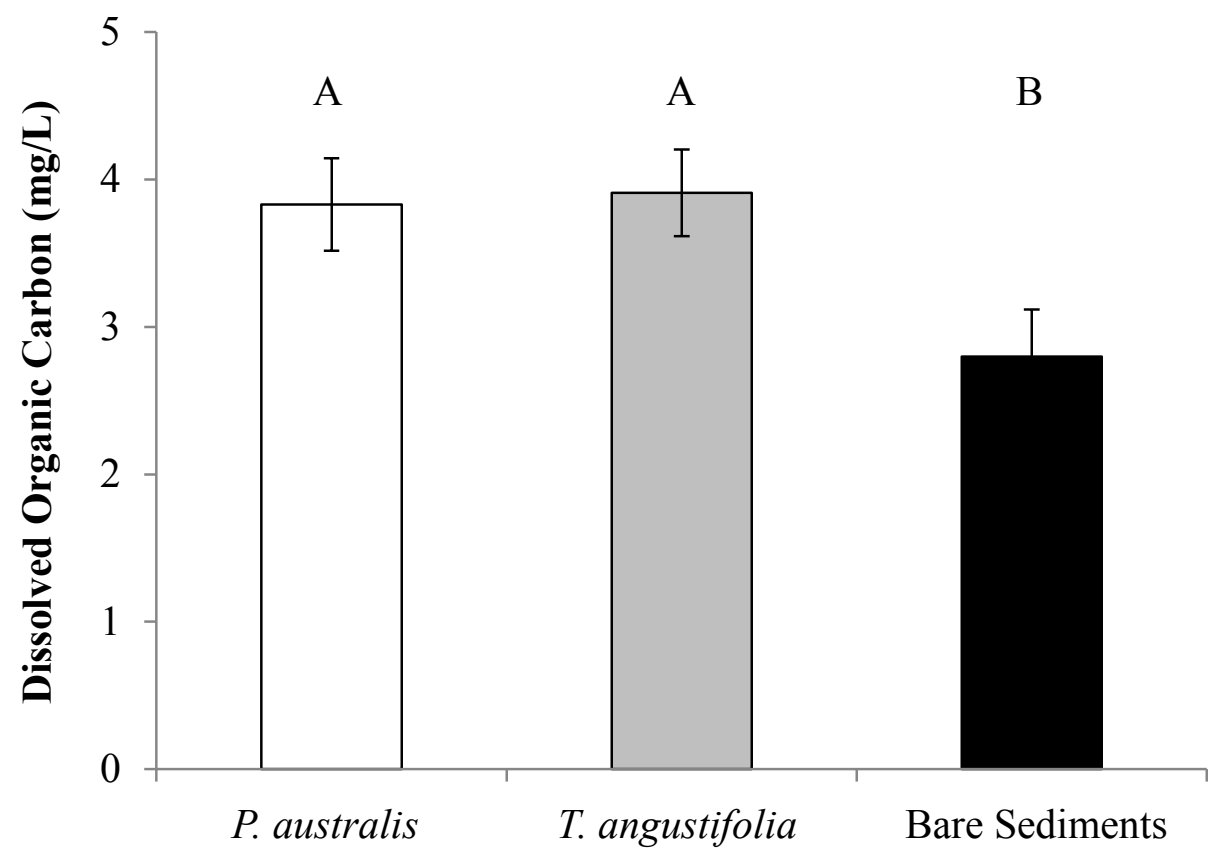

Figure 2. Mean Dissolved Organic Carbon (mg/L) For Each Treatment. Error Bars Represent +/- 1 Standard Error. Means With The Same Letter Are Not Significantly Different Using The REGWQ Method For Pairwise Comparisons. 


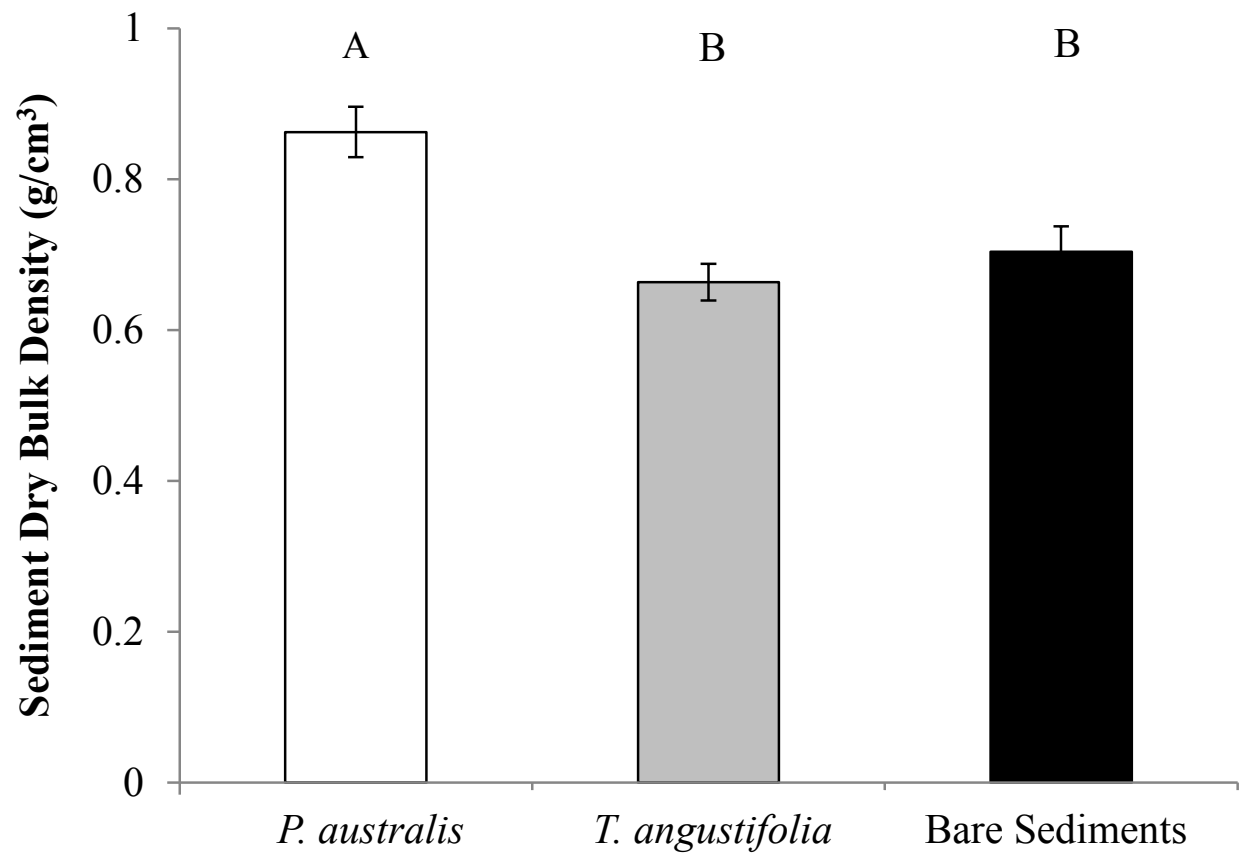

Figure 3. Mean Sediment Dry Bulk Density $\left(\mathrm{g} / \mathrm{cm}^{3}\right)$ For Each Treatment. Error Bars Represent +/- 1 Standard Error. Means With The Same Letter Are Not Significantly Different Using The REGWQ Method For Pairwise Comparisons. 


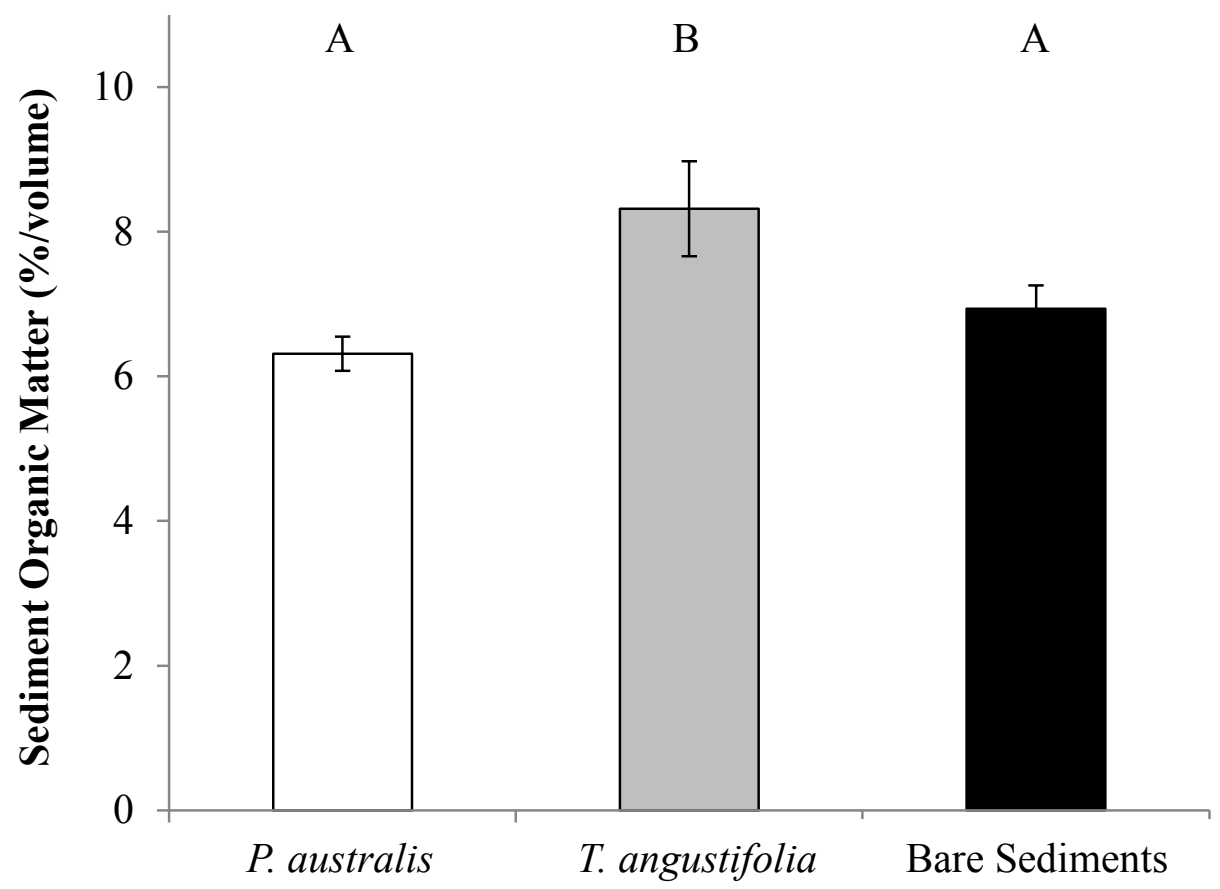

Figure 4. Mean Percent Sediment Organic Matter By Volume For Each Treatment. Error bars represent +/- 1 Standard Error. Means With The Same Letter Are Not Significantly Different Using The REGWQ Method For Pairwise Comparisons. 


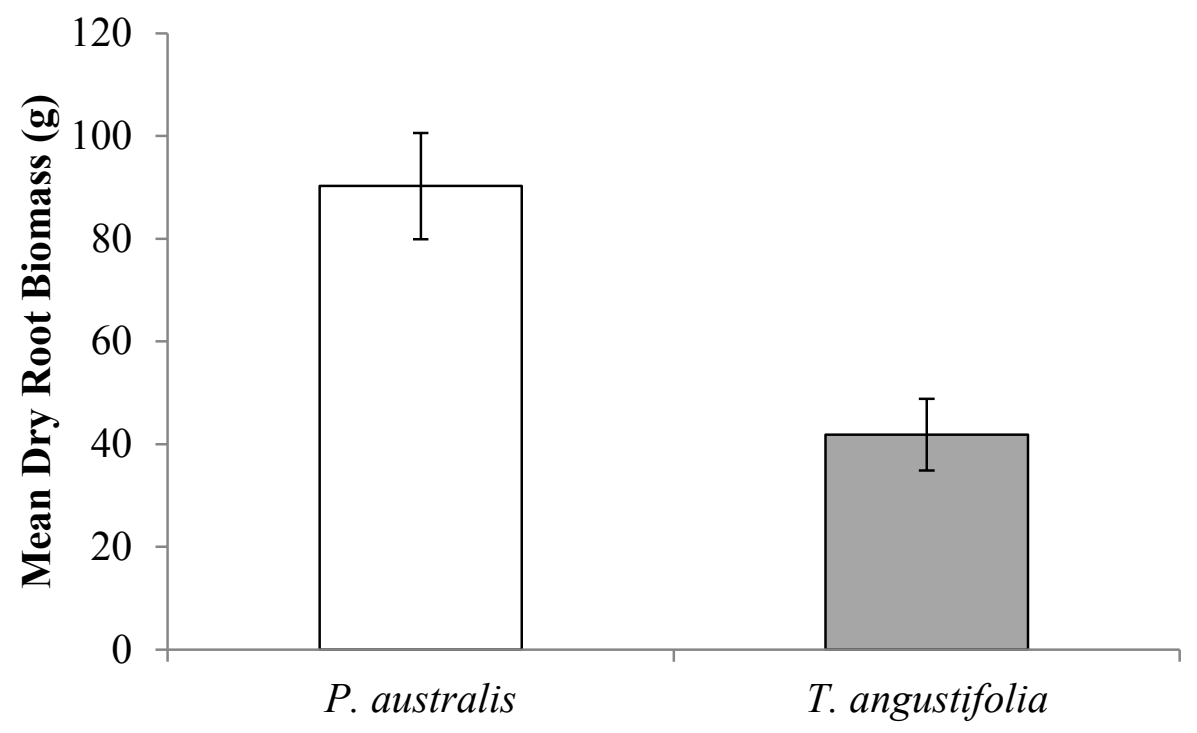

Figure 5. Mean Dry Root Biomass Were Significantly Different Between P. australis And T. angustifolia. Error Bars Represent +/- 1 Standard Error. 


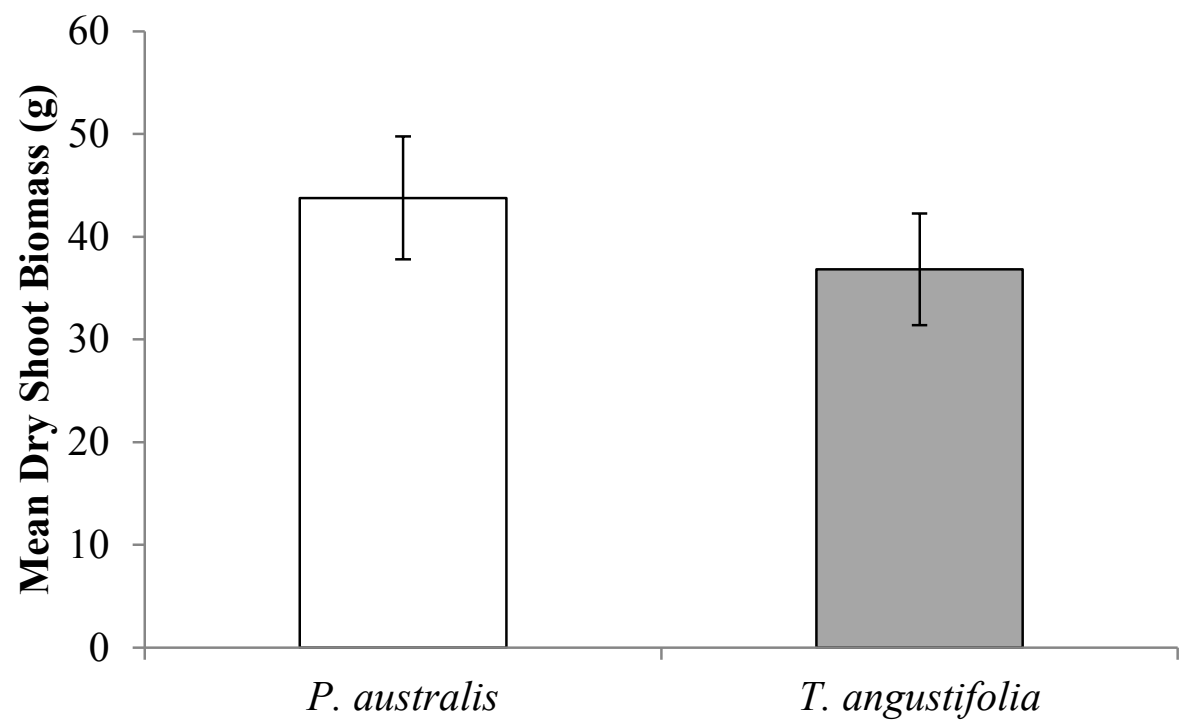

Figure 6. Mean Dry Shoot Biomass (g) Was Not Significantly Different Between $P$. australis And T. angustifolia Treatments. Error Bars Represent +/- 1 Standard Error. 
Table 2. MANCOVA Results For The Dry Root Biomass Covariate And Treatment Interaction

\begin{tabular}{ccccc} 
Source & $\begin{array}{c}\text { Dependent } \\
\text { Variable }\end{array}$ & $\begin{array}{c}\text { Mean } \\
\text { Square }\end{array}$ & F Value & Pr $>$ F \\
\hline RootOM & $\mathrm{NO}_{3}$-N & 0.0994 & 0.02 & 0.9036 \\
Treatment & & 9.0062 & 1.37 & 0.2585 \\
RootOM*Treatment & & 7.1651 & 1.09 & 0.3116 \\
\hline RootOM & $\mathrm{OM}$ & 0.0007 & 1.36 & 0.261 \\
Treatment & & 0.0004 & 0.79 & 0.3878 \\
RootOM*Treatment & & 0 & 0 & 0.9696 \\
\hline RootOM & $\mathrm{Bulk}$ & 0.0043 & 0.52 & 0.4827 \\
Treatment & & 0.0771 & 9.16 & $\mathbf{0 . 0 0 8}$ \\
RootOM*Treatment & & 0.0186 & 2.21 & 0.1569 \\
\hline RootOM & $\mathrm{DOC}$ & 5.032 & 6.93 & 0.0181 \\
Treatment & & 0.0194 & 0.03 & 0.8723 \\
RootOM*Treatment & & 1.0541 & 1.45 & 0.2457
\end{tabular}

$\mathrm{P}$ is significant if $<0.05$. 
Table 3. MANCOVA Results Showing The Effect Of The Covariate Dry Root Biomass By Treatment

\begin{tabular}{ccccc} 
Source & $\begin{array}{c}\text { Dependent } \\
\text { Variable }\end{array}$ & Mean Square & F Value & $\operatorname{Pr}>\mathrm{F}$ \\
\hline RootOM & $\mathrm{NO}_{3}-\mathrm{N}$ & 0.548 & 0.08 & 0.7767 \\
Treatment & & 1.8691 & 0.28 & 0.6014 \\
\hline RootOM & $\mathrm{OM}$ & 0.0008 & 1.64 & 0.218 \\
Treatment & & 0.0015 & 3.06 & 0.0985 \\
\hline RootOM & Bulk & 0.0003 & 0.03 & 0.8672 \\
Treatment & & 0.1009 & 11.19 & $\mathbf{0 . 0 0 3 8}$ \\
\hline RootOM & DOC & 4.0187 & 5.39 & $\mathbf{0 . 0 3 2 9}$ \\
Treatment & & 2.2027 & 2.96 & 0.1037 \\
\hline
\end{tabular}

$\mathrm{P}$ is significant if $<0.05$. 
Table 4. MANCOVA Results Showing The Least Square Means Of The Planted Treatments

H0: LS Mean $1=$

$\begin{array}{llll}\text { Treatment } & \text { Variable LS Mean } & \text { Standard Error } & \text { LS Mean2 }\end{array}$

\begin{tabular}{|c|c|c|c|c|}
\hline P. australis & NO3-N & 7.0697 & 0.9679 & 0.6014 \\
\hline T. angustifolic & & 6.2404 & & \\
\hline P. australis & OM & 0.1547 & 0.0083 & 0.0985 \\
\hline T. angustifolic & & 0.1312 & & \\
\hline P. australis & Bulk & 0.8594 & 0.0358 & 0.0038 \\
\hline T. angustifolic & & 0.6667 & & \\
\hline P. australis & $\mathrm{DOC}$ & 3.4196 & 0.3253 & 0.1037 \\
\hline T. angustifolic & & 4.3198 & & \\
\hline
\end{tabular}

$\mathrm{P}$ is significant if $<0.05$. 


\section{CHAPTER IV \\ DISCUSSION}

We failed to reject the null hypothesis that there would be no difference in nitrate removal across microcosm types. We expected to see differences in DOC and DO concentrations in addition differences in $\mathrm{NO}_{3}-\mathrm{N}$ removal between planted and barren sediment microcosms. DO was not detected in my study, and DOC concentrations were higher in planted microcosms than barren sediment microcosms (Figure 2) but there was not a significant difference in $\mathrm{NO}_{3}-\mathrm{N}$ removal rates (Figure 1). The results are unexpected considering other variables are significantly different. The presence of higher DOC concentrations should have indicated higher $\mathrm{NO}_{3}-\mathrm{N}$ removal rates, but this was not the case. The following sections delve into the interpretation of these results.

\section{$\mathrm{NO}_{3}-\mathrm{N}$ Removal}

There were no significant differences in interstitial porewater $\mathrm{NO}_{3}-\mathrm{N}$ removal rates (Figure 1) in P. australis and T. angustifolia relative to barren sediments. The average $\mathrm{NO}_{3}-\mathrm{N}$ removal rate was $2.22 \mathrm{mg} / \mathrm{L}$ per hour in the greenhouse microcosms. The concentration of $\mathrm{NO}_{3}-\mathrm{N}$ was reduced from $20 \mathrm{mg} / \mathrm{L}$ to 6.92 for $P$. australis, 6.39 for $T$. angustifolia, and $6.66 \mathrm{mg} / \mathrm{L}$ for barren sediment microcosms. My study has found comparable removal rates relative to previous studies which have indicated denitrification rates that vary widely from $0.003-1.02 \mathrm{~g} \mathrm{~N} \mathrm{~m}^{-2} \mathrm{~d}^{-2}$ (Engler and Patrick 1974, Johnson 
1991, Reddy and D’Angelo 1997). If I extrapolated that nitrate removal is consistent in the microcosms then my average removal rate would be $0.03 \mathrm{~g} \mathrm{~N} \mathrm{~m}^{-2} \mathrm{~d}^{-1}$. $\mathrm{NO}_{3}-\mathrm{N}$ would have been removed by biotic uptake by plants as well as by microbial denitrification in planted microcosms, while denitrification would only have been the removal mechanism in barren sediment microcosms. This is interesting because a number of other variables were significantly different between the planted and bare sediment microcosms.

\section{Dissolved Organic Carbon}

The concentrations of interstitial DOC were significantly higher in planted microcosms relative to barren sediment microcosms (Figure 2). However, DOC concentrations were not significantly different between the two macrophyte species $P$. australis and T. angustifolia, with DOC concentrations of 3.83 and $3.91 \mathrm{mg} / \mathrm{L}$, respectively, while barren sediment microcosms had $2.80 \mathrm{mg} / \mathrm{L}$ of DOC. However the MANCOVA indicated the concentration of DOC in the interstitial porewater, which was sampled within the rhizosphere, was significantly correlated with root mass with a pvalue of 0.0329 (Table 3). Both species in this study produce secondary metabolites in their roots that are allelopathic in nature, called phenolic acids, which are toxic to neighboring plants and used in competition for space and sediment resources. As a source of carbon, the allelopathic chemicals could be a driving factor behind $\mathrm{NO}_{3}-\mathrm{N}$ removal by microbes in the rhizosphere but removal was not facilitated by the macrophytes in this study.

The DOC concentrations found in the interstitial porewater were lower relative to surface water DOC concentrations in wetlands and lakes from around North America and Europe that ranged from 4.1-156.2 mg/L (Arts et al. 2000), as well as interstitial 
porewater DOC concentrations in a fjord in Quebec, Canada that reported concentrations between 4.5-35 mg/L (Deflandre and Gagné 2000). Our interstitial DOC concentrations were comparable to eastern Illinois tile drained water samples that with DOC loading concentrations of 2.6-4.6 mg/L (Kovacic et al. 2000). However, while the DOC from tile drainage is leached from organic sources in sediments near the surface of agricultural fields, the source of DOC in this study originated solely from the roots and degrading organic matter within the rhizosphere. The specific forms of carbon in DOC originating from terrestrial sources, however, would be different than DOC originating from within a wetland. In natural systems, carbon sources can include allochthonous leachate from terrestrial plant organic material or autochthonous DOC from submerged or emergent macrophytes, or even algal blooms (Royer and David 2005).

\section{Dissolved Oxygen}

Removing $\mathrm{NO}_{3}-\mathrm{N}$ by microbial denitrification requires anoxic sediment conditions, however in planted wetlands macrophytes transfer oxygen to the roots to maintain living tissues, which would inhibit microbial denitrification. The transfer of oxygen to the roots can increase DO concentrations radially around the roots, creating an oxygenated microzone of approximately $1.7 \mathrm{~mm}$ away from the root surface (Armstrong et al. 2000). When I sampled and tested for DO in the rhizosphere using the Winkler Titrations, I did not detect any oxygen in the sediment porewater despite extensive root systems for both macrophyte species treatments. Based on these results, oxygen was either continually depleted due to microbial respiration or the oxygenated area around the roots was too small to be sampled accurately with the piezometers. The oxygen produced in the roots would have been used preferentially for microbial respiration and $\mathrm{NO}_{3}-\mathrm{N}$ 
would have only been used after dissolved oxygen was depleted. The preference for oxygen for respiration would have delayed removal in the macrophyte microcosms, therefore temporally inhibiting microbial denitrification. The macrophytes not only altered interstitial porewater characteristics, but also significantly altered sediment characteristics.

\section{Sediment Dry Bulk Density}

Sediment bulk density and organic matter in macrophyte treatments also differed significantly from nonmacrophyte treatments. The mass of the plant roots was significantly correlated with the increase in sediment bulk density and differed between macrophyte treatments in the MANCOVA $(\mathrm{P}=0.0038)$ (Table 3). By increasing sediment bulk density (Figure 3), the pore space between sediment particles is reduced. The macrophytes are capable of decreasing the hydraulic conductivity of water in sediments through the growth of their roots, which increases retention of water and increases the likelihood of nutrients being removed either through biotic uptake or microbial denitrification (Brix 1994). An increase in sediment bulk density might also inhibit the ability of water to travel downward into the water table however this could also increase the time water remains in the upper layers of the sediments where $\mathrm{NO}_{3}-\mathrm{N}$ is more likely to be removed.

\section{Sediment Organic Matter}

I analyzed sediment organic matter to estimate carbon release by the macrophytes into sediments during a short-term study that did not have detrital organic matter build up. Sediments were all sampled for the microcosm from the same wetland, so organic 
matter concentrations were initially the same across treatments. At the end of the study $T$. angustifolia had significantly higher sediment organic matter concentrations in the microcosms relative to the other treatments, but $P$. australis and bare sediment microcosms were not significantly different from one another (Figure 4). According to the MANCOVA, the differences in sediment organic matter cannot be explained by root organic mass in the two macrophytes under study. While $P$. australis had a higher root organic mass percentage in the subsamples taken from the microcosms at $77.5 \%$, it was not significantly higher than the $72.7 \%$ root organic mass percentage found in $T$. angustifolia. Therefore the differences in sediment organic mass may either be attributed to an increased amount of cells sloughing off as the roots grew in T. angustifolia microcosms, a higher density of microbes in the rhizosphere, or an increased output of root exudates.

The results from the MANCOVA were significant and indicated that the root mass of each plant had an effect on DOC concentrations within the rhizosphere. The larger the macrophyte's root mass, the higher the DOC concentration that was present in the porewater in the microcosms. Production of root exudates has been well documented in P. australis and T. angustifolia, so this result was expected. Known root exudates for the invasive $P$ australis include 3,4,5-trihydoxybenzoic acid (gallic acid) and/or gallotannins (Rudrappa et al. 2007). However whether gallic acid and/or gallotannins occur in concentrations high enough to be rhizotoxic or represent the whole of DOC in the rhizosphere remains contentious (Weidenhamer et al. 2013). T. angustifolia also excretes allelopathic chemicals, which include o-hydroxycinnamic acid, syringic acid and isoferulic acid, which can suppress growth and germination of neighboring plants and 
phytoplankton (Jarcow and Cook 2009, Zhang et al. 20011). In addition to the release of root exudates, carbon is released from decaying root material and sloughed off cells that are composed of lignin and cellulose. While the rhizosphere might have a selectively stimulatory effect on microbial community activity and composition, $\mathrm{NO}_{3}-\mathrm{N}$ removal may not be affected at the macrophyte species level (Ruiz-Rueda et al. 2009).

\section{Summary}

Despite $P$. australis and T. angustifolia having significantly higher DOC concentrations relative to the bare sediment microcosms, the additional carbon did not facilitate the removal of $\mathrm{NO}_{3}-\mathrm{N}$, and $\mathrm{NO}_{3}-\mathrm{N}$ removal may have been delayed by $\mathrm{DO}$ production. Inhibition of $\mathrm{NO}_{3}-\mathrm{N}$ removal by DO production from the macrophytes was likely a factor that affected $\mathrm{NO}_{3}-\mathrm{N}$ removal as $\mathrm{DO}$ was not detectable in the surface water using a DO meter or in porewater using Winkler Titrations. Furthermore, the higher percentage of organic matter in the sediments from the T. angustifolia treatment did not affect $\mathrm{NO}_{3}-\mathrm{N}$ removal.

Carbon buildup from detritus deposition or algal blooms in wetlands may be the driving force in microbial denitrification, and not simply the presence of a rhizosphere. Further investigation into microbial community structure and enzymatic activity in the presence and absence of macrophyte detritus should be conducted. Emergent macrophyte rhizospheres may act as a substrate for microbial denitrification, as well as promote nutrient cycling and other ecosystem functions, but differential effects on $\mathrm{NO}_{3}-\mathrm{N}$ removal were not detected in this study. 


\section{REFERENCES}

Addy, K., D.Q. Kellogg, A.J. Gold, P.M. Groffman, G. Ferendo, and C. Sawyer. 2002. In situ push-pull method to determine ground water denitrification in riparian zones. J. Environ. Qual. 31:1017-1024.

Angeloni, N.L., K.J., Jankowski, N.C. Tuchman, and J.J. Kelly. 2006. Effects of an invasive cattail species (Typha $x$ glauca) on sediment nitrogen and microbial community composition in a freshwater wetland, FEMS Microbial Letters. 263: 86-92.

Arts, M. T., R.D. Robarts, F. Kasai, M.J. Waiser, V.P. Tumber, A.J. Plante, H. Rai, and H.J. de Lange. 2000. The attenuation of ultraviolet radiation in high dissolved organic carbon waters of wetlands and lakes on the northern Great Plains. Limnol. Oceanogr. 45:292-299.

Armstrong, W., D. Cousins, J. Armstrong, D.W. Turner, and P.M Beckett. 2000. Oxygen Distribution in Wetland Plant Roots and Permeability Barriers to Gasexchange with the Rhizosphere: a Microelectrode and Modeling study with Phragmites australis. Ann. Bot. 86:687-703.

Avnimelech, Y., G. Ritvo, L.E. Meijer, and M. Kochba. 2001. Water content, organic carbon and dry bulk density in flooded sediments. Aquac. Eng. 25:25-33.

Blake, G.R., and K.H. Hartge. 1986. Bulk density. In: Klute, A. (ed.), Methods of soil analysis part 1, Physical and mineralogical methods. J. Am. Soc. Agron. 2:363375.

Boyd, C.E. 1995. Nutrients. In: Bottom soils, sediment, and pond aquaculture. Chapman and Hall, New York. p. 348.

Brinson, M.M., H.D. Bradshaw, E.S. Kane. 1984. Nutrient assimilative capacity of an alluvial floodplain swamp. J. Appl. Ecol. 21:1041-1057.

Brix, H. 1994. Functions of Macrophytes in constructed wetlands. Water Sci. Technol. 29:71-78.

Callaway, R.M. and W.M Ridenour. 2004. Novel weapons: invasive success and the evolution of increased competitive ability. Front. in Ecology. 2:436-443.

Callaway, R.M., D. Cipollini, K. Barto, G.C. Thelen, S.G. Hallett, D. Prati, K. Stinson, 
J. Klironomos. 2008. Novel weapons: invasive plant suppresses fungal mutualists in America but not in its native Europe. Ecology. 89:1043-1055.

Dawson, K.J. and J.D. Istok. 1991. Aquifer testing: design and analysis of pumping and slug tests. Lewis Publishers, Inc.

Dodla, S.K., J.J. Wang, and R.D. DeLaune. 2012. Characterization of labile organic carbon in coastal wetland soils of the Mississippi River deltaic plain: Relationships to carbon functionalities. Sci. Total Environ. 435:151-158.

Engler R.M., and W.H. Patrick Jr. 1974. Nitrate removal from floodwater overlying flooded soils and sediments. J. Environ. Qual. 3:409-413.

Gagnon, V., F. Charzarenc, Y. Comeau, and J. Brisson. 2007. Influence of macrophyte species on microbial density and activity in constructed wetlands. Water Sci. Technol. 56:249-254.

Istok, J.D., M.D. Humphrey, M.H. Schroth, M.R. Hyman, K.T. O'Reilly. 1997. Singlewell, "push-pull" test for in situ determination of microbial activities. Groundwater. 35:619-631.

Jarchow, M.E., B.J. Cook. 2009. Allelopathy as a mechanism for the invasion of Typha angustifolia. Plant Ecology. 204:113-124.

Koop-Jakobsen, K., A.A. Giblen. 2010. The effect of increased nitrate loading on nitrate reduction via denitrification and DNRA in salt marsh sediments. Limnol. Oceanogr. 55:789-802.

Kovacic, D.A., M.B. David, L.E. Gentry, K.M. Starks, and R.A. Cooke. 2000. Effectiveness of constructed wetlands in reducing nitrogen and phosphorus export from agricultural tile drainage. J. Environ. Qual. 29:1262-1274.

Johnston, C.A. 1991. Sediments and nutrient retention by freshwater wetlands: effects on surface water quality. Crit. Rev. Environ. Control. 21:491-565.

Lin, Y.F., S.R. Jing, T.W. Wang, and D.Y. Lee. 2002. Effects of macrophytes and external carbon sources on nitrate removal from groundwater in constructed wetlands. Environ. Pol. 119: 413-420.

Mitsch, W.J., and J. Gosselink. 2000. The value of wetlands: importance of scale and landscape setting. Ecological Economics. 35:25-33. 
Mitsch, W.J., J.W. Day, G. Wendell, P.M. Groffman, D.L. Hey, W.G. Randall, and N. Wang. 2001. Reducing nitrogen loading to the Gulf of Mexico from the Mississippi River Basin: Strategies to counter a persistent ecological problem. BioScience. 51:373-388.

Mook, D.H., and C.M. Hoskin. 1982. Organic Determinations by Ignition: Caution Advised. Estuarine, Coastal Shelf Sci. 15:697-699.

Park, N., Lee, J., Chon, K., Kang, H., Cho, J. 2009. Investigating microbial activities of constructed wetlands with respect to nitrate and sulfate reduction. Desalin. Water Treat. 1:172-179.

Pinton, R., Z. Varanini, and N. Paolo. 2007. The rhizosphere biochemistry and organic substances at the soil-root interface. CRC-Press, Boca Raton.

Reddy, K.R., and E.M. D’Angelo. Soil processes regulating water quality in wetlands. In Mitsch WJ, (ed.) Global wetlands: old world and new. 309-324.

Rickey, M.A., and R.C. Anderson. 2004. Effects of nitrogen addition on invasive grass Phragmites australis and a native competitor Spartina pectinata. J. Appl. Ecol. 41:888-896.

Royer, T.V., and M.B. David. 2005. Export of dissolved organic carbon from agricultural streams in Illinois, USA. Aquat. Sci. 67:465-471.

Rudrappa, T., J. Bonsall, J.L. Gallagher, D.M. Seliskar, and H.P. Bais. 2007. Rootsecreted allelochemical in the noxious weed Phragmites australis deploys a reactive oxygen species response and microtubule assembly disruption to execute rhizotoxicity. J. Chem. Ecol. 33:1898-1918.

Ruiz-Rueda, O., S. Hallin, and L. Baneras. 2009. Structure and function of denitrifying and nitrifying bacterial communities in relation to the plant species in a constructed wetland. FEMS Microbiol. Ecol. 67:308-319.

Singh, B.K., P. Millard, A.S. Whiteley, and J.C. Murrell. 2004. Unraveling rhizosphere-microbial interactions: opportunities and limitations. Trends Microbiol. 12:386-393.

Stelzer, R.S., D.R. Drover, S.L. Eggert, and M.A. Muldoon. 2011. Nitrate retention in a sand plains stream and the importance of groundwater discharge. Biogeochemistry. 107:91-107.

Suloway, L., and M. Hubbell. 1994. Wetland resources of Illinois: an analysis and atlas. Illinois History Survey. 
Thacker, S.A., E. Tipping, D. Gondar, A. Baker. 2008. Functional properties of 247 DOM in a stream draining blanket peat. Sci. Tot. Environ. 407:566-573.

Vitousek, P.M., C.M. Dantonio, L.L. Loope, and R. Westbrooks. 1996. Biological invasion as global environmental change. Am. Sci. 84:468-478.

Tipping, E., H.T. Corbishley, J. Koprivnjak, D.J. Lapworth, M.P. Miller, C.D. Vincent, and J. Hamilton-Taylor. 2009. Quantification of natural DOM from UV absorption at two wavelengths. Environ. Chem. 6:472-476.

Weidenhamer, J.D., M. Li, J. Allman, R.G. Bergosh, and M. Posner. 2013. Evidence does not support a role for gallic acid in Phragmites australis invasion success. J. Chem. Ecol. 39:323-332.

Yannarell, A.C., R.R. Busby, M.L. Denight, D.L. Gebhart, and S.J. Taylor. 2011. Soil bacteria and fungi respond on different spatial scales to invasion by the legume Lespedeza cuneata. Front. Microbiol. 2:1-12.

Zaman, M., M.L. Nguyen, A.J. Gold, P.M. Groffman, D.Q. Kellogg, and R.J. Wilcock. 2008. Nitrous oxide generation, denitrification, and nitrate removal in a seepage wetland intercepting surface and subsurface flows from a grazed dairy catchment. Soil Res. 46:565-577.

Zedler, J.B. 2003. Wetlands at your service: reducing impacts of agriculture at the watershed scale. Front. Ecol. Environ. 1:65-72.

Zhang, T., W. Hu, and D. Zhang. 2012. Allelopathic effect of Typha angustifolia L. on phytoplankton. Adv. Materials Res. 383:3724-3728. 